\section{Using Self-compatible Inbreds of Broccoli as Seed Producers}

\author{
Mark W. Farnham ${ }^{1}$ and Howard F. Harrison ${ }^{2}$ \\ U.S. Department of Agriculture, Agricultural Research Service, U.S. Vegetable \\ Laboratory, 2875 Savannah Highway, Charleston, SC 29414-5334
}

Additional index words. Brassica oleracea, doubled-haploids, broccoli sprouts

\begin{abstract}
The discovery that broccoli (Brassica oleracea L., Italica Group) sprouts contain high levels of sulforaphane, a constituent that may provide chemoprotection against certain carcinogens, has stimulated much interest in seed production of this crop. Studies were undertaken to determine the potential for producing broccoli seed using self-compatible selections from open-pollinated (OP) populations or doubled-haploid (DH) programs. In all outdoor and greenhouse trials, three OP selections and seven DH lines produced selfed seed, but seed weight per plant and number per plant varied significantly among the entries. In all environments there were individuals with relatively high (i.e., $>3 \mathrm{~g} / \mathrm{plant}$ ) production that were significantly different from low (i.e., $<2 \mathrm{~g} / \mathrm{plant}$ ) producers. The relative productivity of some lines varied greatly between experiments, which indicates that seed production of particular genotypes is affected differently by environmental conditions. This indicates the importance of identifying lines that are high producers of selfed seed across different environments. Two OP cultivar-derived lines (USVL102 and USVL104) and two DH lines (USVL062 and USVL093) were identified that consistently produced relatively high yields in greenhouse and screen cage trials. These lines are good candidates for evaluating seed production in field tests and as possible sources of seed for sprouting.
\end{abstract}

Broccoli has received increasing attention in recent years because it contains relatively high levels of glucoraphanin, a glucosinolate, and its isothiocyanate breakdown product sulforaphane (Carlson et al., 1987; Farnham et al., 2000; Faulkner et al., 1998; Kushad et al., 1999). Sulforaphane is a potent inducer of Phase II enzyme activity in mammalian cells (Zhang et al., 1992, 1994) and may provide chemoprotection against certain carcinogens when it is consumed in vegetables (Michaud et al., 1999; Talalay and Fahey, 2001). The discovery by Fahey et al. (1997) that broccoli sprouts (i.e., seedlings) have 10 to 100 times more glucoraphanin than the mature vegetable, and subsequent work with these sprouts and their active components (Brooks et al., 2001; Fahey and Talalay, 1999), has stimulated commercial interest in broccoli seed and sprouts as new food products.

Two pools of broccoli seed are currently available commercially for sprout production. One pool is seed of hybrid cultivars. Since nearly $100 \%$ of commercial vegetable broccoli is produced from hybrids, hybrid seed has been the primary commercial seed product of this vegetable for almost two decades. Broccoli hybrids have been traditionally produced by crossing two inbred lines, each self-incompatible, but cross-compatible with one another (Gray, 1993). Such a system for producing $F_{1}$

Received for publication 13 Feb. 2002. Accepted for publication 28 May 2002. The contents of this publication do not necessarily reflect the views or policies of the USDA, nor does the mention of trade names, commercial products, or organizations imply endorsement by the U.S. Government.

${ }^{1}$ Research Geneticist.

${ }^{2}$ Research Agronomist. hybrid seed of broccoli was first proposed by Pearson (1932). Currently, the costs to produce hybrid seed are high, and the resulting seed is expensive (about $\$ 3.00 / 1000$ seed). The high price of this seed will likely prevent it from becoming an economically viable source of seed for sprouting.

A second available pool is seed of openpollinated (OP) cultivars such as 'Calabrese' or 'DeCicco'. OP cultivar seed production is relatively inexpensive since it is accomplished by allowing open-pollination (and presumably cross-pollination) among plants in a given OP population. This is typically facilitated using insect pollinators. OP cultivars are not used commercially for broccoli production. Instead, they are almost grown exclusively by heirloom gardeners. The recent broccoli seed production increases for sprouting have probably exploited some of the existing OP cultivars. Adisadvantage of the OP seed produced by these cultivars is that it represents a highly heterogeneous mixture of genotypes, and it should follow that seed characteristics, including glucoraphanin level, are highly variable as well.

An alternative source of broccoli seed for sprouting might be obtained by developing self-compatible inbreds that produce large quantities of cheap, homogeneous seed using a production scheme similar to that used to increase heterogeneous OP populations. The presence of self-compatible individuals and some level of selfed-seed production in broccoli, were first documented by Moore and Anstey (1954) in what was previously considered an almost exclusively cross-pollinated crop. Subsequently, some investigators suggested that self-compatible inbreds might be used directly as broccoli cultivars (Gray, 1993). However, the predominance of hybrids in commercial production for the last couple decades reduced interest in this area.

In this study we examine the potential of a limited number of inbreds to produce selfed seed in greenhouse and screen cage environments devoid of pollinators. Our specific objectives were to: 1 ) determine if consistent selfed-seed producers can be selected out of OP populations; 2) evaluate similar selfed-seed producers identified among a diverse population of doubled-haploid (DH) lines (essentially inbreds); and 3) determine if select lines will consistently produce selfed seed in different greenhouse and screen cage environments.

\section{Materials and Methods}

Plant material. Twelve broccoli entries were included in two greenhouse and two screen cage tests. Three entries derive from the OPcultivars Italian Green Sprouting, DeCicco, and Atlantic. In a winter planting in 1997-98, 15 plants of each OP cultivar were grown in a greenhouse, and an individual plant from each cultivar that set a relatively large quantity of seed by selfing independently was identified. Seed was collected from these individuals and maintained as a separate $S_{1}$ seed lot for the greenhouse and screen cage tests. The seed lot derived from 'DeCicco' was designated USVL102; from 'Atlantic', USVL103; and from 'Italian Green Sprouting', USVL104.

Among DH lines developed by the senior author (Farnham, 1998; Farnham et al., 1998), self-compatible individuals that produce relatively large amounts of seed in the absence of insect pollinators have been identified. For studies described herein, the following DH lines were tested: USVL062 and USVL093 derived from the hybrid 'Sultan' (Sakata Seed Co., Morgan Hill, Calif.); USVL036 and USVL043 from the hybrid 'High Sierra' (Seminis Vegetable Seeds, Woodland, Calif.); USVL049 from the hybrid 'Marathon' (Sakata Seed Co.); USVL020 from the hybrid 'Everest' (Syngenta Seed, Gilroy, Calif.); and USVL028 from the hybrid 'Futura' (Seminis Vegetable Seeds).

Two check entries used in these studies were the hybrid 'Pinnacle' (Takii Seed Co., Salinas, Calif.) and the hybrid 'Coronado' (Seminis Vegetable Seeds). 'Pinnacle' is a male-fertile hybrid produced using a traditional SI system. Such hybrids can sometimes produce small quantities of selfed-seed in the absence of pollinators. 'Coronado' is a more recently released hybrid that expresses cytoplasmic male sterility. 'Coronado' served as a check in our greenhouse and screen cage studies since it cannot produce selfed seed. A lack of seed set on 'Coronado' would indicate that no cross-pollination (only self pollination) was occurring in our trials.

Greenhouse trials. A greenhouse trial was conducted at Charleston, S.C., during October through April in 1998-99 and 1999-2000. Temperatures ranged from $\approx 23^{\circ} \mathrm{C}$ during the day to $\approx 13^{\circ} \mathrm{C}$ during night. Ten seed of each of the 12 entries described above were planted (one per cell) in Metromix 360 (Grace Sierra, Milpitas, Calif.) in 200A Speedling polystyrene 
flats (Speedling, Sun City, Fla.) the last week of September. Seedlings were maintained in the trays in the Greenhouse through the last week of October, and then transplanted to 20-cm-diameter pots filled with Metromix 360 and having an effective rooting volume of $4 \mathrm{~L}$. The design of the experiment was a randomized complete block, with plants arranged in five blocks (replications) throughout the greenhouse. Each block contained 12 plants (one for each entry) randomly arranged within each block and spaced so not to touch one another.

Plants were grown in the greenhouse through vegetative stages (November-December), through heading and flowering stages (January-February), and finally seed set and seed maturity (February-April). Pots were watered daily as needed. Plants were well fertilized throughout the study, receiving a weekly watering with a $20 \mathrm{~N}-8.6 \mathrm{P}-16.6 \mathrm{~K}$ nutrient solution containing micronutrients (Peters 20-20-20, Scotts-Sierra Horticultural Products Co., Marysville, Ohio) and a $2.5-\mathrm{g}$ per pot application of granular $10 \mathrm{~N}-4.3 \mathrm{P}-8.3 \mathrm{~K}$ fertilizer, also containing micronutrients, every 3 weeks. Any insect infestations that occurred in the greenhouse were controlled by timely application of registered insecticides. Toward maturity, as plants grew in height, they were staked with bamboo and kept tied to the stakes so that they neither fell nor touched each other.

When plants reached a stage where $\approx 50 \%$ of the siliques were yellowed or brown, all siliques were harvested, regardless of color, by cutting the mature racemes from the plants and placing them in paper bags. Bags with harvested siliques were left in the greenhouse and dried for $\approx 2$ weeks. All seed was then threshed out of siliques and trash was removed from samples by hand. Seed samples were then placed in envelopes and allowed to dry further in a culture room set at $25{ }^{\circ} \mathrm{C}$ and low (i.e., <50\%) relative humidity. After 2 weeks under these conditions, seed was placed into a seed storage facility with temperature and relative humidity set at $10^{\circ} \mathrm{C}$ and $50 \%$ relative humidity, respectively. After equilibrating for $\approx 4$ weeks under these conditions, each harvested seed lot was weighed. In addition, random samples of 100 seed from each seed lot were also weighed to allow estimation of individual seed weight. The number of seed produced by each plant in the experiments was estimated by dividing each total plant seed yield by the respective weight per seed. It was assumed that seed moisture content was similar among all samples because all seed lots were harvested and subsequently handled and stored prior to weighing under the same conditions. Plant maturity varied among entries studied, but this trait was not considered in these experiments.

Screen cage trials. A screen cage trial was conducted at Charleston, S.C., during November through May in 1999-2000 and 2000-01. For these experiments, 10 seed of the same 12 entries used in greenhouse trials were planted in seedling flats during the first week of November. Seedlings were maintained in the trays in the same greenhouse used in greenhouse trials through November, and during the first week of December seedlings were transplanted to pots as described previously. Plants were arranged in three blocks in the greenhouse with two plants of each entry in a given block. Plants remained in the greenhouse through the vegetative growth stage during December and January. This was done to avoid the risk of freeze damage, which is greatest in Charleston from December through January. At the beginning of February, plants were moved to $1.83 \times 1.83 \times 1.83$-m Lumite (BioQuip Products, Gardena, Calif.) screen cages set up outdoors at Charleston. Two plants of each entry were randomly placed in each screen cage and placed so they did not touch one another. Screen cage experiments were arranged in a randomized complete-block design with three blocks where each cage was considered a block. Screen cage plants were grown, watered, fertilized, and staked, and insects were controlled as described for the greenhouse trials.

When plants in screen cages had $\approx 50 \%$ yellow or brown siliques, they were harvested as described for greenhouse experiments. Bags with harvested siliques were placed in the greenhouse and dried for $\approx 2$ weeks. All seed was then threshed out of siliques, and handled and processed as described for greenhouse trials.

Statistical analysis. Analysis of variance (ANOVA) was conducted using Proc GLM of SAS (release 6.12; SAS Inst., Cary, N.C.). Data for total seed weight per plant, the number of seed per plant, and the average individual seed weight per plant were analyzed for all experiments in a combined analysis to test for significant environment, genotype, and genotype $\times$ environment effects. Single degree of freedom contrasts were conducted to test for differences between greenhouse and screen cage environments, between one greenhouse environment and the other, and between one screen cage environment and the other. In addition, the above characters were analyzed for each individual environment to examine genotypic effects in a given environment.

\section{Results}

Broccoli genotypes varied in seed production based on measures of g/plant or number/plant in each of the four experiments (Tables 1 and 2); however, the relative productivity of genotypes was not consistent among experiments. Several genotypes demonstrated consistent seed production levels relative to the others in all greenhouse and screen cage experiments. For example, USVL104 had mean seed weight per plant that ranged from 4.25 to $6.03 \mathrm{~g} /$ plant in the four environments, and USVL020 had means ranging from 2.06 to 2.25 $\mathrm{g} /$ plant. Other genotypes were among the high seed producers in one or more trials but were among low producers in others (Tables 1 and 2). A good example of this is USVL043 that produced $\approx 900$ seed per plant in the greenhouse trials and $<250$ seed per plant in screen cage trials. This apparent genotypic variation in response to environment resulted in a significant
$(P<0.05)$ genotype $\times$ environment interaction detected by ANOVA. Environment means and ranges for seed weight (g/plant) or number per plant across all genotypes were similar, and ANOVA found no significant environmental effect on these traits.

There was no trend toward differences in productivity between the OP cultivar-derived lines and the DH lines (Tables 1 and 2). Both groups were composed of relatively high producing genotypes, such as USVL104 and USVL062 that typically produced more than $3 \mathrm{~g} \mathrm{seed} / \mathrm{plant}$, and also of relatively low producers, such as USVL103 and USVL028 that usually yielded less than $2 \mathrm{~g} /$ plant. The relative productivity of genotypes in either group also varied among experiments.

The $\mathrm{F}_{1}$ 'Pinnacle' was a consistently low (e.g., $<1 \mathrm{~g} /$ plant) seed producer in all experiments, and the $\mathrm{F}_{1}$ 'Coronado' produced no seed in three of four experiments. The amount of seed produced by 'Coronado' in the fourth environment, the 2000-01 screen cage, was negligible compared to all other entries in that experiment.

Genotypes varied in individual seed weight in all environments except the 2000-01 screen cage (Table 3). As with other traits examined, the means and ranges for weight per seed, based on all entries, were very similar at about $4 \mathrm{mg} / \mathrm{see}$ and $3-5 \mathrm{mg} / \mathrm{seed}$, respectively, among environments. Similar to seed $\mathrm{g} /$ plant and number/plant, there was no significant effect of environment on $\mathrm{mg} / \mathrm{seed}$, but there were significant $(P<0.05)$ genotype and genotype by environment effects on this trait. In three experiments, mean weight of the largest seeded genotype was over $50 \%$ greater than the smallest. For instance, in the 1998-99 greenhouse USVL102 had a mean seed weight of $3.2 \mathrm{mg} / \mathrm{seed}$ while USVL043 had a mean of $5.1 \mathrm{mg} / \mathrm{seed}$. No correlation between individual seed weight and seed production per plant was observed. Individual seed weight of most genotypes was more consistent among experiments than seed number/plant org/plant, and similar variation for individual seed weight was observed in both OP cultivar-derived and DH lines.

\section{Discussion}

Plant-to-plant variation and use of a small number of replications in trials described herein resulted in relatively high (e.g., often $>50 \%$ ) coefficients of variation for seed characteristics measured and large least significant differences for mean separation. In spite of this, in all environments there were individuals with relatively high seed production that were significantly different from others exhibiting low seed production. Thus, results indicate OP cultivar-derived selections and DH lines are potential good sources of selfed broccoli seed. This finding is consistent with the previous report of self-compatible broccoli (Moore and Antsey, 1954).

Several entries did not produce a significantly greater amount (g/plant or number/plant) of seed than 'Coronado', which produced no seed in three of four environments. However, 
Table 1. Mean seed weight per plant for three open-pollinated (OP) broccoli lines, seven doubled-haploid (DH) lines, and the check hybrids 'Pinnacle' and 'Coronado' in two greenhouse and two screen cage environments.

\begin{tabular}{|c|c|c|c|c|c|}
\hline \multirow[b]{2}{*}{ Entry } & \multirow[b]{2}{*}{ Source } & \multicolumn{2}{|c|}{ Greenhouse } & \multicolumn{2}{|c|}{ Screen cage } \\
\hline & & 1998-99 & $1999-00$ & $1999-00$ & $2000-01$ \\
\hline & & \multicolumn{4}{|c|}{$-----------\mathrm{g} / \mathrm{plant}^{2}----------$} \\
\hline USVL 104 & $\mathrm{OP}$ & $4.25 \mathrm{a}$ & $6.03 \mathrm{a}$ & $5.16 \mathrm{a}$ & $4.02 \mathrm{~b}$ \\
\hline USVL 102 & OP & $1.63 \mathrm{bc}$ & $2.25 \mathrm{~b}-\mathrm{e}$ & $5.83 \mathrm{a}$ & $8.28 \mathrm{a}$ \\
\hline USVL 103 & OP & $0.96 \mathrm{bc}$ & 0.48 de & $2.59 \mathrm{bc}$ & $1.89 \mathrm{c}-\mathrm{g}$ \\
\hline USVL 062 & $\mathrm{DH}$ & $4.50 \mathrm{a}$ & $1.82 \mathrm{~b}-\mathrm{e}$ & $3.26 \mathrm{~b}$ & $3.69 \mathrm{bc}$ \\
\hline USVL 093 & $\mathrm{DH}$ & $3.39 \mathrm{ab}$ & $3.87 \mathrm{ab}$ & $1.36 \mathrm{c}-\mathrm{e}$ & $2.92 \mathrm{~b}-\mathrm{d}$ \\
\hline USVL 049 & $\mathrm{DH}$ & $2.77 \mathrm{ab}$ & $3.70 \mathrm{bc}$ & $1.41 \mathrm{c}-\mathrm{e}$ & $2.65 \mathrm{~b}-\mathrm{e}$ \\
\hline USVL 020 & $\mathrm{DH}$ & $2.25 \mathrm{a}-\mathrm{c}$ & $2.06 \mathrm{~b}-\mathrm{e}$ & $2.21 \mathrm{~b}-\mathrm{d}$ & $2.23 \mathrm{~b}-\mathrm{f}$ \\
\hline USVL 028 & $\mathrm{DH}$ & $2.44 \mathrm{a}-\mathrm{c}$ & $1.46 \mathrm{c}-\mathrm{e}$ & $1.59 \mathrm{c}-\mathrm{e}$ & $0.79 \mathrm{e}-\mathrm{h}$ \\
\hline USVL 043 & $\mathrm{DH}$ & $4.40 \mathrm{a}$ & $3.82 \mathrm{ab}$ & $0.61 \mathrm{de}$ & $1.06 \mathrm{~d}-\mathrm{h}$ \\
\hline USVL 036 & DH & $2.11 \mathrm{a}-\mathrm{c}$ & $2.46 \mathrm{~b}-\mathrm{d}$ & $0.43 \mathrm{e}$ & $0.49 \mathrm{f}-\mathrm{h}$ \\
\hline Pinnacle & $\mathrm{F}$ & $0.79 \mathrm{bc}$ & $0.38 \mathrm{de}$ & $0.28 \mathrm{e}$ & $0.35 \mathrm{gh}$ \\
\hline Coronado & $\mathrm{F}_{1}$ & $0.00 \mathrm{c}$ & $0.00 \mathrm{e}$ & $0.00 \mathrm{e}$ & $0.01 \mathrm{~h}$ \\
\hline $\mathrm{LSD}_{005}$ & & 2.62 & 2.27 & 1.60 & 1.87 \\
\hline
\end{tabular}

${ }^{2}$ Values for each environment followed by different letters are significantly different as determined by protected least significant difference (LSD) test at $P<0.05$.

Table 2. Mean number of seed per plant for three open-pollinated (OP) broccoli lines, seven doubled-haploid (DH) lines, and the check hybrids 'Pinnacle' and 'Coronado' in two greenhouse and two screen cage environments.

\begin{tabular}{|c|c|c|c|c|c|}
\hline \multirow[b]{2}{*}{ Entry } & \multirow[b]{2}{*}{ Source } & \multicolumn{2}{|c|}{ Greenhouse } & \multicolumn{2}{|c|}{ Screen cage } \\
\hline & & 1998-99 & 1999-00 & 1999-00 & $2000-01$ \\
\hline & & \multicolumn{4}{|c|}{$\begin{array}{l}--------- \text { no. seed } / \text { plant }^{2}---------- \\
\end{array}$} \\
\hline USVL 104 & OP & $967 \mathrm{a}$ & $1884 \mathrm{a}$ & $1372 \mathrm{a}$ & $858 \mathrm{~b}$ \\
\hline USVL 102 & OP & $576 \mathrm{a}-\mathrm{c}$ & $1031 \mathrm{bc}$ & $1705 \mathrm{a}$ & 1859 a \\
\hline USVL 103 & OP & $239 \mathrm{bc}$ & $102 \mathrm{~d}$ & $522 \mathrm{bc}$ & $383 \mathrm{c}-\mathrm{f}$ \\
\hline USVL 062 & DH & $1152 \mathrm{a}$ & $528 \mathrm{~cd}$ & $858 \mathrm{~b}$ & $925 \mathrm{~b}$ \\
\hline USVL 093 & DH & $1041 \mathrm{a}$ & $1233 \mathrm{ab}$ & $457 \mathrm{~b}-\mathrm{d}$ & $722 \mathrm{bc}$ \\
\hline USVL 049 & DH & $664 \mathrm{a}-\mathrm{c}$ & $829 \mathrm{bc}$ & $389 \mathrm{c}-\mathrm{e}$ & $584 \mathrm{~b}-\mathrm{d}$ \\
\hline USVL 020 & DH & $509 \mathrm{a}-\mathrm{c}$ & $502 \mathrm{~cd}$ & $485 \mathrm{~b}-\mathrm{d}$ & $484 \mathrm{~b}-\mathrm{e}$ \\
\hline USVL 028 & DH & $645 \mathrm{a}-\mathrm{c}$ & $392 \mathrm{~cd}$ & $423 \mathrm{c}-\mathrm{e}$ & $217 \mathrm{~d}-\mathrm{f}$ \\
\hline USVL 043 & DH & $868 \mathrm{ab}$ & $901 \mathrm{bc}$ & $148 \mathrm{c}-\mathrm{e}$ & $240 \mathrm{~d}-\mathrm{f}$ \\
\hline USVL 036 & DH & $473 \mathrm{a}-\mathrm{c}$ & $503 \mathrm{~cd}$ & $113 \mathrm{c}-\mathrm{e}$ & $111 \mathrm{ef}$ \\
\hline Pinnacle & $\mathrm{F}_{1}$ & $200 \mathrm{bc}$ & $94 \mathrm{~d}$ & $62 \mathrm{de}$ & $66 \mathrm{ef}$ \\
\hline Coronado & $F_{1}$ & $0 \mathrm{c}$ & $0 \mathrm{~d}$ & $0 \mathrm{e}$ & $2 \mathrm{f}$ \\
\hline $\mathrm{LSD}_{0.05}$ & & 698 & 680 & 429 & 445 \\
\hline
\end{tabular}

${ }^{2}$ Values for each environment followed by different letters are significantly different as determined by protected least significant difference (LSD) test at $P<0.05$.

Table 3. Mean individual seed weight (mg/seed) for three open-pollinated (OP) broccoli lines, seven doubled-haploid (DH) lines, and the check hybrid 'Pinnacle' in two greenhouse and two screen cage environments.

\begin{tabular}{|c|c|c|c|c|c|}
\hline \multirow[b]{2}{*}{ Entry } & \multirow[b]{2}{*}{ Source } & \multicolumn{2}{|c|}{ Greenhouse } & \multicolumn{2}{|c|}{ Screen cage } \\
\hline & & 1998-99 & $\overline{1999-00}$ & 1999-00 & $2000-01$ \\
\hline & & --- & ---- & ${ }^{z}----$ & ---- \\
\hline USVL 104 & $\mathrm{OP}$ & $4.7 \mathrm{ab}$ & $3.2 \mathrm{~cd}$ & $3.8 \mathrm{de}$ & 4.6 \\
\hline USVL 102 & OP & $3.2 \mathrm{e}$ & $2.3 \mathrm{e}$ & 3.4 ef & 4.6 \\
\hline USVL 103 & OP & $3.8 \mathrm{c}-\mathrm{e}$ & $4.0 \mathrm{a}-\mathrm{c}$ & $5.1 \mathrm{a}$ & 5.1 \\
\hline USVL 062 & DH & $3.9 \mathrm{~b}-\mathrm{e}$ & $3.2 \mathrm{~cd}$ & $3.8 \mathrm{de}$ & 4.1 \\
\hline USVL 093 & DH & $3.2 \mathrm{e}$ & $3.1 \mathrm{de}$ & $2.9 \mathrm{f}$ & 4.1 \\
\hline USVL 049 & DH & $4.1 \mathrm{~b}-\mathrm{d}$ & $4.4 \mathrm{ab}$ & $3.7 \mathrm{de}$ & 4.5 \\
\hline USVL 020 & DH & $4.4 \mathrm{a}-\mathrm{c}$ & $4.3 \mathrm{ab}$ & $4.6 \mathrm{ab}$ & 4.7 \\
\hline USVL 028 & DH & $3.7 \mathrm{c}-\mathrm{e}$ & $3.6 \mathrm{~b}-\mathrm{d}$ & $3.7 \mathrm{de}$ & 3.7 \\
\hline USVL 043 & DH & $5.1 \mathrm{a}$ & $4.6 \mathrm{a}$ & $4.1 \mathrm{~cd}$ & 4.6 \\
\hline USVL 036 & DH & $4.2 \mathrm{~b}-\mathrm{d}$ & $4.8 \mathrm{a}$ & $3.9 \mathrm{~cd}$ & 4.2 \\
\hline Pinnacle & $\mathrm{F}_{1}$ & $3.5 \mathrm{de}$ & $4.1 \mathrm{ab}$ & $4.4 \mathrm{bc}$ & 4.0 \\
\hline LSD & & 0.8 & 0.8 & 0.5 & NS \\
\hline
\end{tabular}

${ }^{2}$ Values for each environment followed by different letters are significantly different as determined by protected least significant difference (LSD) test at $P<0.05$.

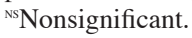

it is important to recognize that the difference between no seed for 'Coronado' and even a small amount of seed in any other entry is biologically significant. The primary reason that 'Coronado' was included in this study was to ensure that no significant cross-pollination was occurring. In the absence of cross-pollination, to vary in different conditions. Selection of a high seed producer, based on data from one environment (e.g., in the greenhouse) will not ensure high production in all environments. To identify consistent and reliable selfed seed producers, it will likely be important to select lines that produce consistent seed yields across environments. A reasonable approach may be to first identify good selfed-seed producers in the greenhouse, determine if they are also good producers in a screen cage, and if so, they may be good candidates for testing in field production. At least two OP cultivar-derived lines (USVL102 and 104) and two DH lines (USVL062 and USVL093) characterized in this research are good candidates for evaluating seed production in future field tests.

\section{Literature Cited}

Brooks, J.D., V.G. Paton, and G. Vidanes. 2001. Potent induction of phase 2 enzymes in human prostrate cells by sulforaphane. Cancer Epidemiol. Biomarkers \& Prevention 10:949-954.

Carlson, D.G., M.E. Daxenbichler, C.H. vanEtten, W.F. Kwolek, and P.H. Williams. 1987. Glucosinolates in crucifer vegetables: Broccoli, Brussels sprouts, cauliflower, collards, kale, mustard greens, and kohlrabi. J. Amer. Soc. Hort. Sci. 112:173-178.

Fahey, J.W. and P. Talalay. 1999. Antioxidant functions of sulforaphane: A potent inducer of Phase II detoxication enzymes. Food Chem. Toxicol. 37:973-979.

Fahey, J.W., Y.Zhang, and P. Talalay. 1997. Broccoli sprouts: An exceptionally rich source of inducers of enzymes that protect against chemical carcinogens. Proc. Natl. Acad. Sci. USA 94:10367-10372.

Farnham,M.W. 1998. Doubled haploid broccoli production using anther culture: Effect of anther source and seed set characteristics of derived lines. J. Amer. Soc. Hort. Sci. 123:73-77.

Farnham, M.W., E.J. Caniglia, and C.E. Thomas. 1998. Efficient ploidy determination of anther-derived broccoli. HortScience 33:323-327.

Farnham, M.W., K.K. Stephenson, and J.W. Fahey. 2000. Capacity of broccoli to induce a mammalian chemoprotective enzyme varies among inbred lines. J. Amer Soc. Hort. Sci. 125:482-488.

Faulkner, K., R. Mithen, and G. Williamson. 1998. Selective increase of the potential anticarcinogen 4-methylsulphinylbutyl glucosinolate in broccoli. Carcinogenesis 19:605-609.

Gray, A.R. 1993. Broccoli, Brassica oleracea L. (Italica group), p. 61-86. In: G. Kalloo and B.O. Bergh (eds.). Genetic improvement of vegetable crops. Pergamon Press, Oxford.

Kushad, M.M., A.F. Brown, A.C. Kurlich, J.A. Juvik, B.P Klein, M.A. Wallig, and E.H. Jeffery. 1999. Variation of glucosinolates in vegetable crops of Brassica oleracea. J. Agr. Food Chem. 47:1541-1548.

Michaud,D.S., D. Spiegelman, S.K.Clinton, E.B.Rimm, W.C. Willett, and E.L. Giovannucci. 1999. Fruit and vegetable intake and incidence of bladdercancer in a male prospective cohort. J. Natl. Cancer Inst. 91:605-613.

Moore, J.F. and T.H. Antsey. 1954. A study of the degree of natural selfing in green sprouting broccoli (Brassica oleracea L. var. Italica Plenck.), a normally cross-pollinated crop. Proc. Amer. Soc. Hort. Sci. 63:440-442.

Pearson, O.H. 1932. Incompatibility in broccoli and the production of seed under cages. Proc. Amer. Soc. Hort. Sci. 29:467-471.

Talalay, P. and J.W. Fahey. 2001. Phytochemicals from cruciferous plants protect against cancer by modulating carcinogen metabolism. Amer. Soc. Nutr. Sci. (Suppl.) 3027s-3033s.

Zhang, Y., T.W. Kensler, C.G. Cho, G.H. Posner, and P. Talalay. 1994. Anticarcinogenic activities of sulforaphane and structurally related synthetic norbornyl isothiocyanates. Proc. Natl. Acad. Sci. USA 91:3147-3150.

Zhang, Y., P. Talalay, C.G. Cho, and G.H. Posner. 1992. A major inducer of anticarcinogenic protective enzymes from broccoli: Isolation and elucidation of structure. Proc. Natl. Acad. Sci. USA 89:2399-2403. 